\title{
Social drivers of fortified settlements in Timor-Leste
}

\author{
Andrew McWilliam
}

\section{Introduction}

In a number of publications, archaeologists Peter Lape and C.-Y. Chao have proposed a 'climate change' model to account for the emergence of fortified structures and 'defensively oriented settlement sites' in Timor-Leste. Specifically, they argue that during the late Holocene (post$A D$ 1000), processes of fortification were driven by severe and rapid climatic events associated with the El Niño Southern Oscillation effect (ENSO) (Chao 2008; Lape 2006; Lape and Chao 2008). The critical ENSO impact was decreasing, leading to variable rainfall and protracted droughts during the period beginning c. $\mathrm{AD}$ 1000, and rising to a peak period $\mathrm{AD} 1300$ 1400. The effect of variable rainfall, it is argued, resulted in food scarcity and gave rise to the construction of defensive fortifications, particularly in areas with permanent water flows that remained agriculturally viable during drought. According to Lape and Chao, people built forts to protect themselves against others who lived in more distant or adjacent regions and who were suffering food shortages.

Lape and Chao advance a number of related factors that purport to support their predictive model of where fortified settlements might be found. They argue that fortifications appeared in the landscape in regions that contained resources tolerant of climate change, thus creating conditions of relative surplus, and that were also adjacent to regions with resources intolerant of climate change, thus creating conditions of relative deficit. To test their predictive model, archaeological investigations were carried out in selected areas of Timor, especially the northeastern coastal districts of Manatuto and Lautem where a series of 28 defensively located hilltop and stonefortified former settlements were excavated and/or sampled. They find general support for their hypothesis, arguing that the spatial data supports a conclusion that fortifications were built preferentially in areas containing drought resistant resources (2008:19).

In the following paper, the utility of this climate-based model of settlement fortification is called into question and an alternative analysis is presented that foregrounds a range of prospective social drivers that might better explain the historical shift towards defensive settlements and the structural characteristics of their built forms. While not discounting the importance of environmental dynamics on Timorese livelihoods and residential choice, a factor that continues to play a significant constraining role in relation to Timorese food security, it is argued that the evidence points more to sociohistorical factors as drivers of change than any marked variations in rainfall patterns and agricultural production. Specifically, I argue that the novel and combined impact of Portuguese colonialism and Sulawesi-based Islamic trading interests from the middle of 
the sixteenth century set in train a transformative shift in Timorese social relations and residential patterns that gave rise to the emergence of fortified hilltop settlements. The paper sets out four central elements of that transformation and, importantly, argues not for a definitive or original date for fortification, for which strong evidence remains elusive, but rather for an historical period of time when the need for a defensive posture became irresistible. ${ }^{1}$

\section{Fortified settlements in Timor: Structure and forms}

Timor is littered with the remnants of old fortified settlement sites, many of which were lived in and used by Timorese communities until well into the twentieth century and remain important cultural sites to the present day. There is therefore a considerable body of ethnohistorical information and local narratives about the use and characteristics of these sites, including their structural functions and significance in former times. In the following analysis, I draw on archaeological and ethnographic interpretations that focus on fortified settlement sites in the far eastern district of Lautem. Here there is a considerable density of fortified sites including a number that have been excavated by Lape (see 2006; Lape and Chao 2008). The region therefore provides a direct comparative context for addressing the Lape-Chao hypothesis.

One important category distinction made by resident Fataluku-speaking farming communities in Lautem is that between former sites of habitation, known as lata paru (past settlements) or lata irinu (old settlements), and the concept of a fortified settlement described by the term pa'amakolo. The latter word is a composite construction of pa'a (to pile up) and makolo (dense or wide walls). Places known as pa'amakolo tend to share a number of common structural features (see also Lape 2006). They include:

- Enclosing structures, commonly comprising double rows of dry stacked limestone walls (1-4 $\mathrm{m}$ in height and 1-2 $\mathrm{m}$ wide at the base), are infilled with a distinctive limestone rubble, known as horo, that litters much of the kastic limestone forest floor in Lautem. The walls form massive perimeter barriers and some sites have a series of walled perimeters in varying degrees of integrity.

- Walled settlements are typically located in highly defensive locations, on hilltops or steep cliffs, and enclose areas ranging from $500 \mathrm{~m}^{2}$ to $3000 \mathrm{~m}^{2}$.

- Many forts feature defensive stone gateways with narrow off-centre entrances that can be guarded from above. Some have slitted apertures suggesting that weapons were used to guard or fire upon the entrances. The gateways typically open onto an internal walled space (laca), which is said to be the area where visitors were greeted.

- Many forts have extensive groves of cactus (including prickly pear) near the entrance and lining the surrounding walls, providing an additional defensive barrier. ${ }^{2}$

- Paiamakolo tend not to have internal water sources, but all are generally located in close proximity to substantial springs. According to local informants, in the past water was stored within the fortified sites in earthenware jars.

- Other common internal features of the sites are massive stone graves (calu luturu), some of which are reported to form large reusable tombs holding numerous burials (poko caru),

1 A modified version of this argument was published in 2012 as S. O’Connor, A. McWilliam, J.N. Fenner and S. Brockwell 2012. Examining the origin of fortifications in East Timor: Social and environmental factors. The Journal of Coastal and Island Archaeology 7(2):200-218, doi.org/10.1080/15564894.2011.619245. That paper focused specifically on the 'origins' of fortification while I am more concerned here with factors that both initiated and reproduced their form.

2 Prickly pear (Opuntia elatior) was an early twentieth-century invasive species in Timor that expanded to plague-like proportions, as it did elsewhere in the region, including Australia. I have argued that it provided a means of encouraging protected settlements out of the mountain forts and into lower-lying terrain (see McWilliam 2000:465). 
ceremonial dancing grounds (sepu) and typically distinctive sacrificial posts (ete uru ha'a or sikua), which remain sites of sacrificial veneration for customary owners of the former settlements.

- All the sites are considered the abode of spirits, and thus potentially dangerous to health and wellbeing. They form part of a complex of beliefs and taboos referred to as tei (pl: teinu), a concept that combines moral authority and protective familiarity with elements of dangerous uncertainty and spiritual retribution.

- A great number of the fortified sites remain actively tended and visited periodically for groupspecific sacrificial rituals and commensal gatherings with group origin ancestors.

\section{Archaeological evidence}

The present paper is based on a collaborative research project between anthropology and archaeology that is exploring the history and prehistory of the distinctive fortified settlements on the island of Timor in eastern Wallacea, which point to a past period of heightened insecurity and inter-group warfare. Three related questions are guiding the research. First, when was the main period for the initiation of fort construction? Second, what were the prevailing environmental and social conditions of those times? And, third what were the key factors that may have motivated people to develop highly defensive settlement locations?

The project has focused enquiries in the Lautem district and teams have excavated a number of sites, including the prominent fortified coastal sites at Ili Vali (near Com) known as MacapainaraSirivairara in 2008 (Chapter 2, this volume), and a fortified site above the present-day settlement of Moro-Parlamento, known as Vasino in 2009 (Chapter 4, this volume). The decision to pursue these particular sites was partly for reasons of access and permission from both local and national authorities, but also to develop a wider comparative repertoire of excavated sites in the region. Preliminary results from the excavations indicate that they provided domestic living spaces in conjunction with their role as defensive fortifications.

In addition to these sites, the project team has located and mapped another dozen or so fortified settlements and collected preliminary data on oral histories, contemporary use and significance from local Fataluku communities who maintain strong cultural attachments to the places in question. These sites are located at Moro-Parlamento, Ira Ara, Tutuala and the forested Vero River valley to the south of Tutuala (Figure 1.1, this volume). The location of sites that includes fortified settlements is illustrated by Lape (2006:286, Figure 1). The map illustrates the relative density of defensive fortified sites in this area of Timor and further survey work is likely to yield additional locations.

During 2008, three test pits were excavated within the fortified headland site, Ili Vali (Macapainara), each to a depth of c. $1.5 \mathrm{~m}$ (see Chapter 2, this volume). The excavations contained abundant earthenware pottery, animal bones, stone artefacts and charcoal, a wide range of shellfish and small quantities of ceramic tradeware from China and Europe. Wild animals were represented at lower levels and domesticates, especially buffalo, pig and dog, predominate in the higher or more recent levels. The assemblages generally confirm Peter Lape's earlier findings, as do the results of preliminary dating for shell and charcoal excavated from the test pits at Macapainara.

Table 6.1 illustrates a sequence of dates derived from Macapainara. The results are quite clear and consistent. Of interest is the range of overlapping time periods for shell and charcoal, which shows that the earliest recorded date is $\mathrm{AD} 1500$ with a concentration of material falling within the seventeenth to eighteenth centuries. 
Table 6.1. Macapainara radiocarbon dates.

\begin{tabular}{|l|l|l|l|l|l|}
\hline Context (spit) & Lab no. (charcoal) & $\begin{array}{l}\text { 28 95.4\% cal. age } \\
\text { range (AD) }\end{array}$ & Lab no. (shell) & $\begin{array}{l}\text { 28 95.4\% cal. age } \\
\text { range (AD) }\end{array}$ & Overlap (AD) \\
\hline A2 & Wk-24947 & $1700-1960$ & Wk-24956 & $1672-1960$ & $1700-1960$ \\
\hline A8 & Wk-24948 & $1690-1950$ & Wk-24957 & $1470-1830$ & $1690-1830$ \\
\hline A13 & Wk-24949 & $1640-1960$ & Wk-24958 & $1430-1720$ & $1640-1720$ \\
\hline C2 & Wk-24950 & $1600-1950$ & Wk-24959 & $1615-1960$ & $1615-1950$ \\
\hline C7 & Wk-24951 & $1690-1960$ & Wk-24960 & $1430-1710$ & $1690-1710$ \\
\hline C13 & Wk-24952 & $1500-1800$ & Wk-24961 & $1420-1720$ & $1500-1720$ \\
\hline D2 & Wk-24953 & $1700-1960$ & Wk-24962 & $1490-1880$ & $1700-1880$ \\
\hline D8 & Wk-24954 & $1650-1960$ & Wk-24963 & $1510-1960$ & $1650-1960$ \\
\hline D15 & Wk-24955 & $1800-1950$ & Wk-24964 & $1290-1550$ & nil \\
\hline
\end{tabular}

Source: From 0'Connor et al. (Chapter 2, this volume).

Preliminary dating of recovered ceramics shows that most of the sherds are of Chinese origin with some likely Vietnamese tradeware. Markings and other visual identifiers give indicative dates of manufacture between the sixteenth and early nineteenth centuries. Tradeware sherds were not found to the base of the artefact-bearing deposit, indicating that habitation of the site may have been established as early as the fifteenth century, which coincides with a period when tradeware was in short supply (Bulbeck 1992). The ceramic dates appear to be in close agreement with the radiocarbon dates for charcoal. They point to an origin for the fortifications at Ili Vali, suggesting that the fortification pattern was undertaken no earlier than the sixteenth century.

In support of this finding, one of our colleagues, Jack Fenner, has undertaken a Bayesian analysis for the charcoal-based dates from Macapainara (Chapter 2, this volume). His analysis demonstrates that there is a 99.6 per cent probability that the material derives from post-AD 1500, and an 89 per cent probability that it does not appear before 1650 . By 1725 the probability factor is down to 68.9 per cent, falling to 28.4 per cent by 1775 . Based on this analysis, the early date probabilities for charcoal cluster around the early eighteenth century.

Comparing these findings with those reported by Lape and Chao (2008; Chao 2008) finds several correspondences. Chao (2008), for instance, excavated a series of fortified hilltop sites in the Manatuto district (100 km west of Lautem on the north coast) during 2004-2006. While a range of radiocarbon dates was obtained from eight locations, fully 70 per cent of the identifiable sherds were dated within the period 1550-1650, and a further 22 per cent of the samples in the period 1650-1725. In other words, 92 per cent of the excavated material postdates AD 1550. Just 5 per cent of the sherds were dated prior to 1550. Lape and Chao acknowledge that 'the hilltop sites in Manatuto were mostly occupied from the mid-16th to the early 18th century AD' (2008:18). Data derived from the fortified sites in Tutuala/Lautem (Lape 2006; Lape and Chao 2008), using a combination of radiocarbon, OSL, TL and AMS 3 dating techniques, obtained a wider range of dated material ranging from $2300 \mathrm{BC}$ to $\mathrm{AD} 1920$. However, as Lape and Chao acknowledge, these sites may have been occupied prehistorically, but 'were likely fortified in the 15th-19th centuries AD' (2008:16).

3 Optical stimulated luminescence (OSL), thermo-luminescence (TL) and accelerator mass spectrometry (AMS) radiocarbon dating. 


\section{Assessing the evidence}

How does this new information mesh with the Lape and Chao model of climate change-induced defensive settlements? We think there are a number of logical and evidential problems. First, among the findings of recent analysis and dating of excavated material from the site Macapainara is the confirmation of a concentration of radiocarbon dates around the seventeenth century, while preliminary dating of Chinese and possibly Vietnamese ceramic sherds reveals a range of material from the sixteenth to early nineteenth centuries. These dates are in general accord with those published by Lape and Chao (2008), who found that the majority of the dates for the fortified sites they analysed clustered within the AD 1450-1650 period. More specifically, they note that the hilltop sites in Manatuto were the only places that people chose to live by the sixteenth and seventeenth centuries, while numerous earlier sites 'on terraces and floodplain were abandoned during this period' (Lape and Chao 2008:18). They acknowledge the 'problematic disjunction' between their model and the calibrated dating of the fortified sites sample, that cluster 'around the 1450-1650AD period, which is later than the El Niño frequency peak of 1300-1400AD', and which they have argued was the climatic precursor to fortification (2008:19). ${ }^{4}$ Their best response is that these later sites may have arisen:

as a result of social forces indirectly related to resource shortages and may have been an adaptation to a system that had already begun to be fortified several hundred years earlier. $(2008: 19)$

The fact is, however, that there is little evidence of this earlier systemic process of climate-induced fortification.

The Lape and Chao model relies heavily on the viability of agriculture in close proximity to fortified settlements, particularly the existence of irrigated cropping of cereals in order to make their case: 'Land even just a few hundred metres away from the river may be totally unproductive if it is too difficult to irrigate' $(2008: 14)$. The logical difficulty with this argument is that the principal pattern of livelihood in Timor for centuries, as far as we can tell (Glover 1972; Oliveira 2008), has been a mixture of swidden farming and hunter-gathering regimes that are highly attuned to seasonality and optimise the use of multiple food resources. A concentration on irrigated cereal agriculture was the exception and highly restricted in area. The further assumption that group mobility, and therefore access to wider food resources, was constrained by clan boundaries and limited by internecine rivalries is not credible. Mobility and social alliances across boundaries are fundamental features of Timorese traditional upland agricultural systems and have their cultural roots in antiquity. While mutual enmities and feuding were undoubtedly a feature of these clanbased identities, limited population numbers constrained any capacity to guard boundaries from interlopers.

Another logical problem can be described under the general principle that 'poor folks do not generally attack rich folks'. If there were groups of people who suffered acute food shortages due to drought, they would be unlikely to attack fortified groups who had all the advantages of resources and numbers to prevail. It seems much more likely that prosperous fortified settlement communities would direct their aggression towards similarly equipped counterparts who represented more direct threats. ${ }^{5}$ The premise of defending attacks from the impoverished starving margins is therefore an unlikely one and unsupported by any material evidence.

4 It is somewhat misleading to make the comment that 'In all three areas fortifications appear on the landscape between 11501550 AD' (Lape and Chao 2008:18). In fact, the 1150 date from Manatuto was only found in one isolated charcoal date when the great majority of dates lie between the sixteenth and eighteenth centuries (Lape and Chao 2008:18). Problems with the radiocarbon calibration curve are also acknowledged, which can return uncertainties spanning 200 years.

5 Thanks to Jack Fenner for this observation. 


\section{Social drivers of fortification}

In exploring the possibility of alternate drivers for settlement fortification, I do not discount the influence of dynamic environmental effects on Timorese livelihoods. Reid, for example, has argued that the period AD 1640-1670 was very dry in Southeast Asia, with deleterious socioeconomic consequences (1993:291-298). But this period does not coincide with the critical period presented in the Lape and Chao model, nor is it clear that these effects had any significant influence on the Timorese environment. By contrast, we would argue that, in the case of Timor-Leste, the evidence points much more strongly to social drivers of change in settlement patterns than it does to environmental factors signalled by marked variation in rainfall distribution. This argument is one that aligns much more closely with the available archaeological evidence, particularly the conclusion that the impetus and widespread emergence of fortified settlements occurred in a period postdating the early sixteenth century (1500s) and well into the seventeenth century.

The history of Timor during this period coincided with a series of intense economic and social transformations linked to a unique combination of factors. Specifically, these influences centred on the arrival of European colonialism in the guise of Portuguese and later Dutch trading interests and corresponded with the emergence of powerful Islamic sultanates in eastern Wallacea, all vying for economic and political advantage. The impact of this volatile convergence of interests had demonstrable, dramatic and long-term repercussions for island societies in the archipelago, Timor included. While the specific contours of these repercussions cannot be charted with precision, there are four significant social drivers of change that are likely to have had major impacts on Timorese social relations and livelihoods, and may well have promoted fortified settlement strategies. The four interrelated drivers of changing settlement strategies comprise: (1) a sandalwood trading boom from the late sixteenth century; (2) the introduction of maize as a staple food crop into Timor in the same period; (3) new trade in advanced weaponry, particularly artillery and firearms; and (4) a significant increase in demand for trade in human slaves. I deal below with each of these prospective social drivers separately, but it is evident that there may well be considerable overlap and correspondences between the elements, which could have contributed to intensified pressures on local residential communities, particularly in far eastern Timor-Leste. I suggest that these processes, or some combination of effects, may well have led to inter-group conflict, reprisals and defensive fortifications.

\section{Increased demand for sandalwood (1580s-1700)}

The intricate history surrounding the sandalwood trade from Timor has been the subject of numerous detailed studies (e.g. Boxer 1947, 1948; de Roever 2002; Fox 1977; Gunn 1999; Ormeling 1956). All highlight the ancient origins of the trade and its association with early Javanese sea merchants and Chinese traders. The advent of the Portuguese and later Dutch trading interests, specifically in search of sandalwood trading profits, dramatically increased the political complexity of maritime trading relations and led to an unremitting plunder of stocks across the island from the mid-seventeenth century.

Direct Portuguese sandalwood trading in Timor was initiated in the early sixteenth century, when trading relations were established with strategic ports on the north coast such as Manatuto, Adê (Vemasse), Com (Lautem) and Lifau (Oecussi). By the early seventeenth century, the demand and extraction of high-quality white sandalwood (Santalum album) had expanded significantly. Profits in sandalwood were substantial, as much as 100 per cent return on investment by the 1590 s 
(Ptak 1987:103-4), which by then far outweighed the potential profits to be gained from beeswax and slaves, two other sought-after commodities. As Hägerdal notes, these latter commodities, 'were certainly of enduring interest to traders of the archipelago but would probably not have motivated ambitious European schemes of exploitation of Timor in their own right' (2012:12).

Boxer cites the case of:

[A]n English merchant who called at Batavia (Java) in 1625, reporting that between 10 and 22 Portuguese galliots called at Macassar [Sulawesi] yearly from Macao, Malacca and ports on the Coromandel coast. They arrived in December and left again in May, using Macassar as an entrepôt for the sale of Chinese silks and Indian cotton textiles, which they exchanged for sandalwood in Timor. (1948:177)

Antonio Bocarro, writing in 1635, highlighted the importance of the sandalwood trade and noted that ' $[\mathrm{I}] \mathrm{n}$ fact sandalwood became so popular that it was used as a kind of currency in the Solor-Timor area' (cited in Ptak 1999:105).

An important component of the sandalwood trade was that profits also accrued to local Timorese rulers and their political allies who supplied the fragrant timber from the coastal ports and obtained prized trading goods in exchange. According to the chronicle of Duarte Barbosa (1521:196), ships going to Timor picked up the mainstay products of sandalwood, honey, beeswax and slaves, against the payment of an array of external goods: iron, axes, knives, swords, cloth from Pulicat in India, copper, mercury, vermillion, tin, lead and coral (beads) from Cambay in India). Another seventeenth-century observer, Saris, spoke of the sandalwood sold (along with 'great cakes' of beeswax) in the markets of Bantam for 'great profit', and traded 'against items of high regard in Timor such as; chopping knives, small bugles, porcelain, coloured taffaties and pieces of silver' (cited in Gunn 1999:65). Similarly, early Dutch observer, Crijn van Raemburch (1614), commented:

$[\mathrm{O}] \mathrm{n}$ Timor in buying sandalwood one must engage in endless negotiations with the king and noblemen. The felling and transportation to the coast is carried out by the ordinary people. The greater part of the profits go to the rulers. (cited in Ormeling 1956:177)

Timorese political communities best placed to profit from the boom in sandalwood trade were those with exclusive access to and control over productive sandalwood resources, much of which flourished on the raised, red calcareous soils and monsoon forest vegetation in the hinterlands of Timor. If the extent to which rivalries over the control and production of sandalwood contributed to the emergence of fortified settlements in the region remains uncertain, the lucrative bounty and material wealth that could be gained through trade undoubtedly contributed to a degree of competition and possible resource conflicts between rival centres. Control over sandalwood production and trade brought prosperity and enhanced status to well-placed political communities, making them possible targets of avarice among neighbouring groups.

The high point of trading in sandalwood was reached by the mid-eighteenth century, but it remained profitable until well into the nineteenth century and provided an important source of economic benefits for favoured coastal communities. By way of example, the Portuguese historian Figueiredo recorded the comments of former Timor-Leste Governor Viera Godinho (1784), who was complaining about the volume of contraband trade occurring with Dutch, Chinese and Makassarese merchants dealing 'especially in sandalwood and slaves' (2000:710-711). 


\section{The introduction of maize}

The advent of an aggressive Portuguese colonialism in the Timor region also brought with it a number of associated developments that had a significant impact on Timorese livelihoods and demographics. One of these developments was the introduction and adoption of maize (Zea mays) as a staple crop in Timorese food production. While there is no clear evidence for precisely when maize was introduced in Timor, it is reported to have been established in neighbouring Maluku by the 1540s where it could have easily been transported to Timor (Cinatti 1964:180). ${ }^{6}$ By 1658 it was already reported as the main crop in western Timor (Reid 1993:19; Hägerdal 2012:30). ${ }^{7}$ From 1672 the Dutch VOC (Vereenigde Oostindische Compagnie: the Dutch East India Company) was also active in promoting the production and dissemination of maize as part of an attempt to improve native cultivation (Fox 1977: 76).

William Dampier, who visited the north coast of Timor in 1699, made some relevant observations on patterns of Timorese livelihoods. He noted that:

Their common subsistence is Indian corn which every man plants for himself. They take little Pains to clear their land; for in the dry Time, they set Fire to the withered Grass and Shrubs, and that burns them out a Plantation for the next wet season. What other grain they have besides Indian corn, I know not. Their plantations are very mean; for they delight most in hunting; and here wild

Buffaloes and Hogs enough, though very shy, because of their so frequent hunting. (1703:170)

The introduction of maize represented a major change in Timorese diets and allowed for substantial food surpluses and very likely higher populations. ${ }^{8}$ According to Fox, for example, maize probably replaced a multi-crop swidden system based around millet with some rice, legumes and tubers, which would have supported a population of less than 10 to 14 persons per $\mathrm{km}^{2}$. Maize, by contrast 'provided the Timorese with the potential to support a population several times that density' (Fox 1988:268).

There is in fact very little direct historical documentation of the demographic impact of the widespread adoption of maize across Timor. But one of the consequences, as Fox has suggested, is that maize 'seems to have triggered local group expansion among the Timorese' where 'voracious methods of slash and burn cultivation required new land and produced a mobile society of shifting local cultivators' (1988:269). The long-term effects of this expansion of shifting cultivation included a marked decline in the forest ecology across the island, but a more immediate impact may well have been increased competition over land and food resources among growing populations and therefore a point of tension between rival groups.

\section{Trade in firearms and gunpowder (sixteenth to eighteenth centuries)}

Perhaps the most important social driver for inducing defensive strategies among Timorese populations was the development of a bourgeoning trade in firearms and gunpowder. Logically this factor may well have given rise to the characteristic features of fortified defensive settlements

6 Timor was for several centuries within the colonial administrative sphere of Ambon (Maluku)-based traders.

7 Cinatti also cites a report of 1624 that identifies maize (zaburro) as 'so inexpensive that it has become the main nourishment of the natives' (1964:183). However, Cinatti acknowledges that the term zaburro was also indistinctly employed for sorghum and some varieties of millet.

8 Other New World crops that found their way into Timorese cultivation systems and continue to provide important supplementary food production include pumpkin/squash (Cucurbita spp.), cassava (Manihot utilissima Pohl.), sweet potato (Ipomoea batatas Poir.), peanuts (Arachis hypogaea), papaya (Carica papaya L.) and tomato (Solanum lycopersicum), among others. 
in far eastern Timor with the use of coralline rubble (horo) as a dense filler between two rows of dry stacked stonewalls. Certainly, comments from local Timorese colleagues readily identify the massive stone walls as a defence against penetrating firearm attack.

Although cannon and gunpowder were Chinese inventions and had been known for centuries, it was the arrival of the Portuguese in the Indian Ocean at the end of the fifteenth century, with far superior weaponry, that irrevocably changed the nature of Asian maritime trade and power relations. ${ }^{9}$ As Chase has argued:

[W] hat had brought the Portuguese to Calicut in India in 1498 was spices, but it quickly became apparent that they had nothing anyone wanted, except bullion from the New World, to exchange for those spices. Fortunately for the Portuguese, what they did have were cannon ... Operating at such a great distance from their home country, Portuguese ships relied on superior firepower to offset superior numbers ... The Portuguese advantage was not commercial but military. (2003:134)

Chase offers the following description of the Portuguese caravels that were positioned off the Malabar (Kerala) coast in 1501.

Each of the caravels carried thirty men and four heavy guns below, and above, six falconnets and ten swivel guns placed on the quarter deck and in the bows, and two of the falconnets fired astern; the ships carried six guns below on the deck, and two smaller ones on the poop, and eight falconnets above and several swivel guns, and before the mast two smaller pieces which fired forwards. (2003:134)

Bristling with firepower, the Portuguese used their military advantage to considerable effect through what Chase refers to as the 'organised use of violence for economic means' (2003:134). As a diplomatic tool, Portuguese firearms were also given away to curry favour with local rulers. This was despite their own reluctance to arm potential rivals and despite papal bans on selling of weapons to 'infidels' (Chase 2003:138; see also Boxer 1965). For other groups who resisted Portuguese entreaties, the response was typically more belligerent. An early report of Portuguese efforts to engage the sandalwood trade directly on Timor provides a sense of the methods employed. As Gunn notes,

The expedition of Jorge Fogasa, undertaken in 1516 successfully brought back to Malacca lucrative amounts of sandal. But it was also apparently the case that Fogasa resorted to force in the act of collection, perhaps sowing the seeds of future conflict. As recorded in a letter from Malacca to King Manuel (Portugal) 'they left a land in revolt, since the Portuguese men bludgeoned the merchants of the land'. (1999: 55)

Timor-Leste, in particular, appears to have been a target of Portuguese coercive trading strategies. Hägerdal, for example, has argued that in East Timor (in contrast to the western portion of the island), Portuguese expansion was 'to a much higher degree a question of brute force' and they had a poor reputation for 'brutal and overbearing treatment of local grandees and populations. The domains were smaller and weaker than in the west and easily fell prey to a determined military' (2012:19-20).

In the low-technological Timorese society, firearms, western methods and maritime skills had a severe impact. Small detachments of muskateers would be decisive for the outcome of armed conflict on the island ... The mobility of the sea borne Portuguese [and later Dutch] gave them the possibility to keep large stretches of the coastland in check. (2012:28)

9 Chinese sources from the 1500 s and 1600s are full of comments on the superior quality of foreign firearms, and foreign observers likewise commented on the inferior quality of Chinese ones. China acquired European muskets sometime in the mid-1500s (Chase 2003:145). 
Hägerdal's point is supported by Gunn who argues in relation to the colonising process that:

Portuguese incorporation was not achieved without extremes of violence, acts of high plunder and massive deracination if not genocide of the victims of such unequal exchanges in naval and military technology. (1999:15)

As has been noted, the Timor trade in sandalwood and, to a lesser extent, in beeswax ${ }^{10}$ and slaves (see below) provided the Timorese with access to outside goods; namely, basic commodities such as iron tools and luxury goods such as cloth, alcohol and porcelain plates. But significantly, as Fox has commented, above all the trade provided a means of warfare, a steady supply of muskets (1988:270). Aggressive maritime colonialism and access to weapons, especially firearms, exacerbated conditions for armed warfare, rebellion and punitive raiding between Timorese residential communities. These factors contributed in no small way to establishing a long-term social and political environment of violent conflict conducive to the development of fortified structures and, in the process, the emergence of an elaborate cult of headhunting across Timor (see Forbes 1885; McWilliam 1996). Hägerdal makes a similar point, writing that, it is just possible that intra-island warfare was stimulated in the course of the seventeenth century by the intervention of foreign groups' noting that 'there is rarely or never mention of firearms and gunpowder traded for sandalwood in the early historical sources (prior to the 1620s)' (2012:19). ${ }^{11}$ This period includes long-term Chinese engagement in sandalwood and associated trading in Timor, which appears to have been negotiated on generally peaceful terms.

The most popular firearms were lightweight and mobile ones: muskets and swivel guns (Chase 2003:139; also Andaya 1992:388). As more manoeuvrable cannon and muskets were introduced by Europeans and later manufactured in Southeast Asia, this tended to give rise to a small number of powerful kings able to monopolise the new technology in their domains (Reid 1988:128). A further key factor in the dissemination of firearms into Timor and the wider region was local production of weapons, probably initiated by the Portuguese distribution of weapons to their native allies. ${ }^{12}$ Reid (1988:136) has noted that, under King Tunipalangga (15481566), bricks, gunpowder, cannons and various other items were first manufactured in Makassar (Sulawesi). Reportedly, by the turn of the seventeenth century, King Matoaya of Tallo (South Sulawesi) introduced the manufacture of cannons and small muskets, and was himself 'skilled at making gunpowder, fireworks and flares, as well as being an accomplished marksman' (Villiers 1985:44-45). At this time, the Makassarese ruler of Goa (South Sulawesi) could reportedly bring '100,000 men into the field armed with blowpipes, poisoned arrows and four thousand guns, most of them obtained from the Portuguese' (Villiers 1983:42)..$^{13}$ As Reid notes, '[i]n practical terms, [those] rulers able to deploy handguns effectively were the ones best able to transform the political landscape in their favour' (1988:224).

The fall of the Portuguese-controlled trading entrepôt Malacca to the Dutch in 1541, saw the Makassarese kingdoms rise in importance and trading influence. Converting to Islam in 1605, Makassar had grown into an important state by 1630 , exercising suzerainty not only throughout Sulawesi but extending to Seram and Buru and as far as Timor, Solor and Bima (Gunn 1999:77).

10 Beeswax has long been exported from Timor. Collected from wild honeybee hives in forest trees, the wax became particularly popular during the nineteenth century to serve the bourgeoning batik industry.

11 Timor also produced the ingredients necessary for the early Catholic Dominican Order's gunpowder manufacture. The earth yielded saltpetre, which the local rulers offered, 'willingly to the religious' and there was wood from which charcoal could be made (Villiers 1985:70).

12 Villiers has observed that 'in exchange for rice and other commodities ... the Portuguese provided the Makassarese with European and Japanese firearms and weapons for which they gained a special papal dispensation from the prohibition against selling weapons to unbelievers' (1985:41, see also descriptions by Boxer 1965).

13 By the early seventeenth century, the Portuguese were being pressured by the growing strength of the Dutch VOC and initially found useful allies in the Makassarese. 
A key event in the Timor context was the maritime attack in 1640 on Portuguese and Timorese settlements by the Makassarese King of Tallo, Toemamalijang (also known by his Islamic name, Moezhaffar). Although estimates vary, the attack on the Portuguese fortification at Larantuka (eastern Flores), involved up to 150 ships and some 6000 men. They then sailed on to Timor, where the fleet split, half heading to the south coast of Timor, the remainder sailing along the northeast coast where they 'vanquished' the strategic Timorese ports of Manatuto, Adê and Hon, ${ }^{14}$ which subsequently came under their control (de Roever 2002:235). ${ }^{15}$ The capacity of Makassarese maritime power can be appreciated in the following early seventeenth-century observation of Torres in his voyages into the Arafura Sea;

At the extremity of this country [Southern Philippines/Maluku] we found some clothed Moors, with artillery for service, such as falconets and swivel guns, arquebuses ${ }^{16}$ and white weapons. They go conquering these people who are named Papuas and preach to them the sect of Mahomed'. (Letter of Luis Vaez de Torres, July 1607 in de Morga 1964:415)

There is little documentation of the impact of these attacks on Timorese settlements, but at the very least the events highlight the uncertain and conflict-riddled times of seventeenth-century Timor. This was a period when armed reprisals and threats were always closely entangled with opportunities for maritime-based trade, and where defensive fortifications and a ready supply of firearms and gunpowder were the strategic technologies of the day. ${ }^{17}$ As a potential driver for the emergence of fortified settlements in Timor, the coercive threat of attack with high-powered weaponry may well have been a central factor.

It is worth noting that the value of firearms to Timorese communities continued unabated for generations. In his description of Timor in 1829, for example, Müller stressed the importance of muskets to the Timorese: ${ }^{18}$

The trade in flintlock rifles is the most advantageous ... that can be conducted on Timor ... The rifle belongs, above all, to the most important piece of inheritance, to the costliest valuable that can pass from father to son; indeed a Timorese would often more easily and more happily do without a house and livestock, even a wife and child, rather than without such a weapon. (1857: Vol. 2 234, cited in Fox 1988:270)

\section{The slave trade}

The fourth and final prominent driver for change in premodern Timor was the rise of commercial slavery and the trade in human beings as part of a broader engagement with maritime trading powers. Slavery has a long and ignoble history in eastern Wallacea, where control over labour was always a critical component of local power relationships and a measure of political status. Forms of debt bondage within hierarchical patron-client relationships were therefore common features of the island societies and bonded individuals (slaves) became defined as a strata of social

14 Likely to be a version of the Lautem coastal port known as Com.

15 The attack also reached the nearby island of Alor, a Makassarese dependency, although the Dutch, according to VOC Governor General Cornelis Speelman, refused to recognise the claim (de Roever 2002:236).

16 An earlier and rather unwieldy form of the matchlock musket.

17 Makassarese trading dominance on the northeastern ports of Timor continued until the successful Dutch attack on Makassar itself in 1667, after which the region was subject to renewed struggles for economic advantage between the Dutch and Portuguese.

18 During the eighteenth and nineteenth centuries, firearms became widespread on Timor and were apparently conducive to the disappearance of traditional weapons such as blow pipes, bows and shields (Hägerdal 2010:115). They remained an ubiquitous possession of all Timorese households until the late twentieth century. It was only in West Timor during the mid-1980s, for example, that muskets and various homemade firearms stopped being used as an everyday item, following sustained police pressure to confiscate civilian-held weapons. 
status. As Reid has noted, 'the system of bonding based on debt was one where loyalties between "owner" and "slave" were strong and intimate, but also became transferable and saleable' (Reid $1988: 129) .{ }^{19}$

Slaves as a tradeable commodity are mentioned in the earliest accounts of European records of contact with Timor. Barbosa's account from 1518, identifies 'sanders-wood, honey, wax, slaves and also a certain amount of silver' as traded items from the island (Dames 1921:195-96). Slavery in eastern Wallacea flourished following both the adoption of Islam across the Indonesian archipelago and the rise of European mercantilism and colonialism in Southeast Asia. As Reid has noted, with the Islamisation of Java and the extension of sharia law forbidding enslavement, the major Muslim cities from the late sixteenth century were supplied with slaves from beyond the frontier of Islam. Certain small Islamic sultanates, notably Sulu, Buton (Sulawesi) and Tidore (Maluku) began to make a profitable business of raiding for slaves in eastern Wallacea (Reid 1988:133). A further attraction of sourcing slaves from non-Islamised islands like Timor, as Reid has also observed, was that '[s] ince slave export [is] almost invariably linked with internal disunity, the stateless societies and micro-states of eastern Indonesia, New Guinea, Bali and Nias were consistently among the exporters' (1988:133). Drawing on the records of the Catholic Dominican Order mission archives for the period 1568-1579, Artur de Sá records observations that:

for some years Muslim traders (Mouros) arriving in Timor via Makassar (in Sulawesi) were trading for sandalwood (sandâlo), beeswax (cera) and slaves (escravagem) from two settlements on Timor, Manatuto and Adê. (cited in McWilliam 2007a:223)

A key impetus for slaving and slave-trading in the eastern archipelago, including Timor, was the Dutch (VOC) violent acquisition of the islands of Banda in neighbouring Maluku from 1621. This action was part of their attempts to monopolise the production and trade in spices, notably nutmeg and mace for which Banda was a key source (see Andaya 1991:83). As Fox has noted:

After establishing their first fortification, the Dutch set about, in 1621, to enslave, expel or exterminate the entire local population of the islands that they controlled, to divide the productive nutmeg producing land into parcels (perken), and then to repopulate the islands with slaves and indentured convicts from all parts of the Indies. (1991:9)

While the documentary evidence of slave-trading from the eastern extremities of Timor at this time is patchy, it is apparent that Timor and particularly the eastern end of the island were closely drawn into the slaving trade networks. Evidence for this development is derived from fragmentary historical documentation and the ethnohistories of resident Fataluku communities. According to Sutherland (1983:267), for example, the Dutch East India Company (Vereenigde Oostindische Compagnie, or VOC), with their endless need for labour, drew upon indigenous slave-trading networks and probably stimulated their expansion and intensification. Kisar, the small island off the northeast coast of Timor, became a transit station for slaves who were sent to work in the nutmeg plantations on Banda (Rodenwaldt 1927:19). At the time, the Dutch were particularly desperate for slaves following the forceful deportation of the native inhabitants from Banda and the view that slaves from areas such as Malabar and the Papuan islands were vulnerable to various types of illness (Andaya 1991:83).

The subsequent decision by the VOC in 1689 forbidding the use of slaves from large tracts of the western archipelago because of their 'record of violence against their masters', increased demand for slaves from the east. So-called 'freeburgers' and 'Mardykers' (freed slaves of Christian Asian origin) were licensed to supply the VOC and relied on their extensive knowledge of local trade networks to secure quality slaves (Andaya 1991:83; Ellen 2003). Although local merchants were

19 Ellen noted of the premodern Moluccas islands, 'slaves traditionally are distinguished between those exchanged or bought ... and those captured in war' (2003:41). 
initially excluded by the VOC from dealing in slaves, as with the spices trade, they were soon able to evade the controls and to profitably restore their involvement (Andaya 1991:88). The attraction of sourcing slaves from eastern Wallacea was officially enhanced by a Dutch colonial ordinance of 3 October 1703, which permitted voyages to Timor and Makassar (Sulawesi) specifically to obtain slaves under licence from the Governor General of the VOC (Fox 1983:259).

If the scale of the commercial export of slaves out of Timor during the colonial period is indeterminate and may never have reached the proportions reported for neighbouring islands such as Sumba and Manggarai in western Flores, there was always a ready market for Timorese slaves. This was a fact reported by numerous observers until the late nineteenth century (see, for example, de Freycinet 1827; Gunn 1999; Kolff 1840). ${ }^{20}$ Gunn reports, for example, that 'by the end of the seventeenth century (1699) the Timor trade in sandalwood, gold, wax and slaves had become Macau's main source of revenue' (1999:79). More significantly, George Earl, who travelled to Timor in the 1850s, makes the following comments about the Lautem region of far eastern Timor:

The slaves, who once constituted the chief article of export from the Portuguese settlements on the island, were chiefly obtained, either by force or barter, from these tribes, and were usually brought to the settlements overland ... They are described as being extremely cautious in their transactions with strangers, even with those who have held intercourse with them for years; and probably they have good reason to be so, for the great slave mart of the Bughis and Macassar traders, Kapalla Tanah, or the Land's-End, is in their immediate neighbourhood. $(1853: 181,182)$

The traders are allowed to land, but not to leave the beach, even to procure water which when their visitors require a supply, is brought down by the natives themselves in bamboo buckets and deposited on the beach. (1853:183)

Two points are worth highlighting here. First, the site that Earl refers to as 'Kapalla Tanah, or the Land's-End' (Headland), is most probably a translation of the old Fataluku name of Valu Beach, Mua Cao Pasaré ('the Headland market'), where local ethnohistorical accounts support Earl's description of trade, and where it is recalled that human slaves (akanu), whether war captives or debt bonded dependants, were regularly traded for gunpowder and ammunition. ${ }^{21}$

An insight into those dynamics can be appreciated from the oral histories of residents of the port settlement of Com, to the north and west of Kapalla Tanah. Com port is a sheltered natural anchorage, which has long served as an entrepôt for regional trading opportunities (see McWilliam 2007b). Oral histories of the senior clans of the settlement, Konu Ratu, point to an enthusiastic historical engagement in slaving and sandalwood trading. According to their testimony, there is a strong relationship between endemic warfare, the maintenance of fortified settlements and the enslavement of rival groups as war captives. Konu controlled the port of Com (a Portuguese corruption of the word Kon(u), taken from the resident land owning group) from their fortified settlements (Kon ara and Lor lafae) overlooking the anchorage. Their strategic position enabled them to control the terms of trade. In particular, for the supply of able-bodied human slaves, they secured key exchange goods in the forms of muzzle-loader guns (fotu), ammunition (fotu kafu) and gunpowder (aranaku). Local tradition also points to regular exchanges with Makassarese (Sulawesi) traders, for gunpowder transported in large bamboo containers. In these exchanges one large bamboo container was traded for one human slave (tau tau ukani = máalaubana

20 When Kolff visited Dili in 1825, he commented that, 'Slaves were frequently offered to me on sale, the Commandant among others, wishing me to purchase two children of seven or eight years of age, who were loaded with heavy irons. The usual price of an adult male slave is forty guilders, that of a woman or child being from twenty five to thirty. These unfortunate people are kidnapped in the interior and brought to Dili for sale, the Governor readily providing the vendor with certificates under his name and seal, authorizing him to dispose of the captives as he may think fit' (1840:34-35).

21 Another trade item that local Fataluku recall as a prized trade item was ' $k$ oichila' or custard apples that were widely propagated in the area and were another Portuguese import from the 'New World' (see Cinatti 1964:185). 
ukani). The benefits of this trade were significant and during this (undated) period, the Konu Ratu leadership gained the reputation as being $\operatorname{Orang} \mathrm{Kai}^{22}$ (from Malay meaning 'wealthy'). According to local knowledge, Konu Ratu formerly owned large numbers of slaves who served the ruling house, preparing gardens, tending animals, cutting timber and tapping palms for the production of liquor (tua harak). Additional slaves for trade were also secured from allied ratu (clans) in the hinterland; all seeking weaponry to defend their home territories and avoid the threat of enslavement themselves should they be unable to repel their enemies.

A second point raised by the Earl observations on slave-trading is that it was evidently still in operation at the time of his visit, but we gain no insight into the origins of the trade in the region, and therefore how long the 'great slave mart' had been operating. In this regard an important historical feature of the eastern extremity of Timor has been its long-term engagement with Bugis and Makassarese traders from Sulawesi. The maritime attack by the Makassarese King of Tallo, Toemamalijang, in 1640 subordinated the coastal ports on the northeast coast of Timor, which lasted until 1667 when the Dutch conquered the city of Makassar itself. In the interim, Timorese settlements felt the impact of a three-way struggle for control between Portuguese, Makassarese and Dutch authorities. De Roever (2002:235) reports that subsequently some of the 'rajas' of East Timor began offering an annual tribute to Makassar that included 50 slaves as well as stockpiles of sandalwood. It is also reported that the Makassarese came yearly with five, six, or more ships and traded (bees)wax, sandalwood, tortoiseshell and amber in return for cloth (see Coolhaas 1968:Vol. III 930).

Slave-trading and the lucrative opportunities for trading in human cargo were therefore important elements in the political and economic dynamics of premodern Timor, one that inevitably made enemies out of others and fostered a social climate of defensive readiness. The regional slave trade out of Timor continued for centuries and experienced renewed intensity in the late eighteenth and early nineteenth centuries, this time partly in relation to indigenous political centralisation elsewhere in eastern Wallacea, especially the regional sultanates of Ternate, Tidore and Buton (Ellen 2003:102).

\section{Conclusions}

In their 2008 paper on environmental drivers for fortification, Lape and Chao draw inferences from the contemporary record of dynamic variations in monsoon rainfall across Timor to compare the sometime grievous impacts of weather patterns on rural livelihoods. Drawing by analogy on the damage that occurred to seasonal maize production in Timor-Leste during the 1997-1998 ENSO, they suggest that 'the unpredictability of precipitation, timing and stability during El Niño events may have had similar catastrophic impacts on other crops with similar scheduling regimes' (Lape and Chao 2008:15). ${ }^{23}$

These patterns are undoubtedly influential factors affecting subsistence food production and rural livelihoods for a majority of Timor-Leste households. They often result in crop losses and, sometimes, outright crop failure, leaving Timorese farmers struggling with food shortages and reduced circumstances. This is a long-term legacy of the uncertain monsoon environment

22 A term used widely across the Malay trading world, including the neighbouring islands of Moluccas where the Orang Kaya represented an oligarchy of elders from small but wealthy communities who had established a 'mercantile aristocracy' (see Villiers 1981:728-729; also Goodman 1998).

23 The argument here is partly based on the assertion that most rainfall in Timor occurs during November to March with little precipitation at other times, and that the main El Niño effects are typically felt in the period December-February. While this is true for the north coast of Timor-Leste, it is by no means the norm elsewhere. The southern hinterland, for example, experiences double or extended monsoon rainfall seasons, and much of Lautem in the far east receives a substantial period of rainfall during May to July, allowing for increased food production and multiple cropping (see Lape and Chao 2008:15). 
in which they live and one that has encouraged the development of highly resilient Timorese communities who focus on diversified food production, foraging strategies and complex exchange relationships that reproduce enduring forms of social capital.

In this paper, I have argued that these features of Timorese social and economic life are certainly important adaptive mechanisms for successful livelihood strategies and that seasonal variation in rainfall patterns may well put additional stress on different communities at different times. But we do not see evidence that these environmental stress factors are causally implicated in the emergence of fortified stone structures in Timor. To the contrary, the weight of evidence points to an enthusiastic process of defensive fortification emerging in eastern Timor well after the high point of the great El Niño warming that had peaked by the beginning of the fifteenth century (AD 1400). The drivers of that later process, I propose, were fundamentally social ones and intimately linked with the transformative changes that accompanied the advent of European colonialism and the development of aggressive Muslim maritime trade in the eastern Indonesian archipelago. Guns, sandalwood, slaves and new forms of sustenance provided a novel and potent mix created by globalised mercantile forces that combined to produce a social climate fostering conflict and favouring defensive residence. I do not discount the possibility that climatic factors may have contributed to these pressures, and future archaeological and ethnohistorical investigations will seek to expand the available evidence in this regard, but to date the weight of argument looks to be in favour of social drivers.

\section{References}

Andaya, L.Y. 1991. Local trade networks in Maluku in the sixteenth, seventeenth and eighteenth centuries. Cakalele: Maluku Research Journal 2(2):71-96.

Andaya, L.Y. 1992. Interactions with the outside world and adaptation to Southeast Asian Society, 1500-1800. In N. Tarling (ed.), The Cambridge history of Southeast Asia. Volume 1. Cambridge University Press, Cambridge. doi.org/10.1017/chol9780521355056.008.

Barbosa, D. 1521. A description of the coasts of East Africa and Malabar in the beginning of the sixteenth century. Translated by H.E.J. Stanley. Hakluyt Society, London. www.gutenberg.org/files/38253/ 38253-h/38253-h.htm. Accessed 21 March 2020.

Boxer, C.R. 1947. The topasses of Timor. Indisch Institut, Amsterdam.

Boxer, C.R. 1948. Fidalgos in the Far East, 1550-1770: Fact and fancy in the history of Macao. Nijhoff, The Hague.

Boxer, C.R. 1965. Asian potentates and European artillery in the sixteenth to the eighteenth centuries: A footnote to Gibson-Hall. Journal of the Malaysian Branch of the Royal Asiatic Society 38(2):156-172.

Bulbeck, F.D. 1992. A tale of two kingdoms: The historical archaeology of Gowa and Tallok. Unpublished $\mathrm{PhD}$ thesis, Australian National University, Canberra.

Chao, C.-Y. 2008. A microregional approach to the social dynamics in the Late Prehistoric Manatuto, East Timor, 11th-18th century. Unpublished PhD thesis. University of Washington, Seattle.

Chase, K. 2003. Firearms: A global history to 1700. Cambridge University Press, Cambridge.

Cinatti, R. 1964. Useful plants in Portuguese Timor: An historical survey. Actas, Colóquio Internacional de Estudos Luso-Brasileiros 1:177-190.

Coolhaas, W.P. (ed.) 1968. Generale Missiven van Gouverneurs-Generaal en Raden aan Heren XVII der Verenigde Oostindische Compagnie, 1665-1674. Volume 3. Nijhoff, Gravenhage. 
Dames, M.L. (ed.) 1921. The book of Duarte Barbosa. The Hakluyt Society, London.

Dampier. W. 1703 (1939). A voyage to New Holland in the year 1699. Volume 3 Part 2. Argonaut Press, London.

de Freycinet, L.C.D. 1827. Voyage autour du Monde, execute sur les corvettes S.M. l'Uranie et la Physicienne pendant les années, 1817, 1818, 1819, 1820: Historique du voyage. Tome, Paris. doi.org/10.5962/bhl. title.63985.

de Morga, A. 1964. The Philippine Islands, Moluccas, Siam, Cambodia, Japan and China at the close of the sixteenth century. Translated by H.E.J. Stanley. Hakluyt Society, London.

de Roever, A. 2002. De Jacht op Sandelhout: De VOC en de Tweedeling van Timor in de Zeventiende Eeuw. Walburg Pers, Zutphen.

Earl, G.W. 1853. The native races of the Indian archipelago: Papuans. H. Bailliere, London. doi.org/10.5962/ bhl.title.101733.

Ellen, R. 2003. On the edge of the Banda zone: Past and present in the social organization of a Moluccan trading network. University of Hawai'i Press, Honolulu. doi.org/10.1515/9780824844608.

Figueiredo, F. 2000. Timor. In A.H. de Oliviera Marques (ed.), História dos Portugueses no Extremo Oriente, Volume 3, pp. 697-793. Fundação Oriente, Lisboa.

Forbes, H.O. 1885. A naturalist's wanderings in the Eastern archipelago: A narrative of travel and exploration from 1878 to 1883. Harper and Brothers, New York. doi.org/10.5962/bhl.title.36489.

Fox, J.J. 1977. The harvest of the palm: Ecological change in Eastern Indonesia. Harvard University Press, Cambridge, Massachusetts.

Fox, J.J. 1983. 'For good and sufficient reasons': An examination of early Dutch East India Company ordinances on slaves and slavery. In A. Reid (ed.), Slavery, bondage and dependency in Southeast Asia, pp. 246-262. University of Queensland Press, St Lucia.

Fox, J.J. 1988. The historical consequences of changing patterns of livelihood on Timor. In D. WadeMarshall and P. Loveday (eds), Contemporary issues in development: Northern Territory: Progress and prospects, Volume 1, pp. 259-279. North Australia Research Unit, The Australian National University, Darwin.

Fox, J.J. 1991. Before Cook: 18th century accounts of life in Eastern Indonesia. Unpublished paper presented at the National Library of Australia, Canberra.

Glover, I. 1972. Excavations in Timor: A study of economic change and cultural continuity in prehistory. Unpublished PhD thesis. The Australian National University, Canberra.

Goodman, T. 1998. The sosolot exchange network of Eastern Indonesia. In J. Miedema, C. Ode and R.A.C. Dam (eds), Perspectives on the bird's head of Irian Jaya: Proceedings of the conference, Leiden, 13-17 October 1997, pp. 421-454. Editions Rodopi B.V., Amsterdam.

Gunn, G.C. 1999. Timor Loro Sae: 500 years. Livros do Oriente, Macau.

Hägerdal, H. 2012. Lords of the land, lords of the sea: Conflict and adaptation in early colonial Timor, 1600-1800. KITLV Press, Leiden. doi.org/10.26530/oapen_408241.

Kolff, D.H. 1840. Voyages of the Dutch brig of war Dourga through the southern and little-known parts of the Moluccan archipelago and along the previously unknown southern coast of New Guinea performed during the years 1825 and 1826. Translated by G.E. Earl. James Madden and Co., London.

Lape, P.V. 2006. Chronology of fortified settlements in East Timor. Journal of Island and Coastal Archaeology 1(2):285-297. doi.org/10.1080/15564890600939409. 
Lape, P.V. and C.-Y. Chao 2008. Fortification as a human response to late Holocene climate change in East Timor. Archaeology in Oceania 43(1):11-21. doi.org/10.1002/j.1834-4453.2008.tb00026.x.

McWilliam, A. 1996. Severed heads that germinate the state: History, politics, and headhunting in Southwest Timor. In J. Hoskins (ed.), Headhunting and the social imagination in Southeast Asia, pp. 127-166. Stanford University Press, Stanford.

McWilliam, A. 2000. A plague on your house? Some impacts of Chromolaena odorata on Timorese livelihoods. Human Ecology 28(3):451-469. doi.org/10.1023/A:1007061632588.

McWilliam, A. 2007a. Looking for Adê: A contribution to Timorese historiography. Bijdragen tot de Taal-, Land-en-Volkenkunde 163(2/3):221-238. doi.org/10.1163/22134379-90003684.

McWilliam, A. 2007b. Harbouring traditions in East Timor: Marginality in a lowland entrepôt. Modern Asian Studies 41(6):1113-1143. doi.org/10.1017/s0026749x07002843.

Oliveira, N.V. 2008. Subsistence archaeobotany: Food production and the agricultural transition in East Timor. Unpublished PhD thesis. The Australian National University, Canberra.

Ormeling, F.J. 1956. The Timor problem: A geographical interpretation of an underdeveloped island. J.P. Wolters, Groningen.

Ptak, R. 1987. The transportation of sandalwood from Timor to China and Macao, c. 1350-1600. In R. Ptak (ed.) Portuguese Asia: Aspects in history and economic history (sixteenth and seventeenth centuries), pp. 87-109. Franz Steiner Verlag, Stuttgart.

Ptak, R. 1999. China's seaborne trade with South and Southeast Asia 1200-1750. Aldershot, Singapore.

Reid, A.J. 1988. Southeast Asia in the age of commerce 1450-1680. Volume 1. Yale University Press, New Haven.

Reid, A.J. 1993. Southeast Asia in the age of commerce 1450-1680. Volume 2. Yale University Press, New Haven.

Rodenwaldt, E. 1927. Die Mestiezen auf Kisar. Med Dienst Volksgez 2dlm, gr 8 Deel 1(XVII).

Sutherland, H. 1983. Slavery and the slave trade in South Sulawesi 1660s-1800s. In A. Reid (ed.), Slavery, bondage and dependency in Southeast Asia, pp. 263-285. University of Queensland Press, St Lucia.

Villiers, J. 1981. Trade and society in the Banda Islands in the sixteenth century. Modern Asian Studies 15(4):723-750. doi.org/10.1017/s0026749x0000874x.

Villiers J. 1985. East of Malacca. Calouste Gulbenkian Foundation, Bangkok. 
This text is taken from Forts and Fortification in Wallacea: Archaeological and Ethnohistoric Investigations, edited by Sue O'Connor, Andrew McWilliam and Sally Brockwell, published 2020 by ANU Press, The Australian National University, Canberra, Australia.

doi.org/10.22459/TA53.2020.06 